\title{
ILCEA
}

Revue de l'Institut des langues et cultures

d'Europe, Amérique, Afrique, Asie et Australie

$40 \mid 2020$

English for Specific Purposes (ESP) and the Underlying Dynamics of Power, Empowerment and Disempowerment

\section{Power Struggles in Aeschylus' Oresteia: ESP, Law and Literature and Greek Tragedy}

Luttes de pouvoir dans l'Orestie d'Eschyle : anglais de spécialité, droit et littérature et tragédie grecque

\section{Malcolm Harvey}

\section{OpenEdition}

\section{Journals}

Electronic version

URL: http://journals.openedition.org/ilcea/10741

DOI: 10.4000/ilcea.10741

ISSN: 2101-0609

\section{Publisher}

UGA Éditions/Université Grenoble Alpes

\section{Printed version}

ISBN: 978-2-37747-204-8

ISSN: 1639-6073

\section{Electronic reference}

Malcolm Harvey, «Power Struggles in Aeschylus' Oresteia: ESP, Law and Literature and Greek Tragedy », ILCEA [Online], 40 | 2020, Online since 04 June 2020, connection on 06 September 2020. URL : http://journals.openedition.org/ilcea/10741 ; DOI : https://doi.org/10.4000/ilcea.10741

This text was automatically generated on 6 September 2020

(C) ILCEA 


\section{Power Struggles in Aeschylus' Oresteia: ESP, Law and Literature and Greek Tragedy}

Luttes de pouvoir dans l'Orestie d'Eschyle: anglais de spécialité, droit et littérature et tragédie grecque

Malcolm Harvey

\section{Introduction}

1 In a departure from mainstream ELP ${ }^{1}$ studies and their primary focus on the language of the law, this paper is situated in the broader perspective of French ESP studies, which reflects the dominantly academic background of ESP in France and other Continental European countries. While the use of contemporary specialised popular fiction (novels, films, TV series, video games, etc.) in $\mathrm{LSP}^{2}$ has attracted considerable research interest in France and elsewhere since the identification and codification of a relatively new genre known as fiction à substrat professionnel (FASP), ${ }^{3}$ this paper seeks to go a step further, exploring possible convergences between ESP and the Law and Literature (L\&L) movement.

2 The genesis of L\&L is generally traced back to two eminent US jurists in the early 20th century: John Henry Wigmore, famous for his work on evidentiary law, and Benjamin Cardozo, a Supreme Court judge. In 1908 Wigmore provided an annotated list of lawrelated novels which, he claimed, reflected or indeed contributed to legal reforms and provided lawyers with an essential insight into human nature, an ethical approach which was to become an enduring feature of L\&L studies. Cardozo analysed the role of style in judicial opinions, arguing that the voice of authority can speak with "supreme literary excellence" (1925: 699).

3 Half a century later L\&L became an established academic field in the US, ${ }^{4}$ initiated by White's The Legal Imagination (1973). The work is a casebook for law students, using 
mainly literary extracts to help them engage creatively with the language of law. Literature and literary criticism are viewed as part of a liberal arts education, enabling trainee lawyers to become more fulfilled and humane practitioners. Weisberg, a jurist with a PhD in comparative literature, spearheaded the movement. He argues that literature sheds light on law with regard to both style and "poethics", using literary texts to warn lawyers of the dangers of manipulative communication and to stress the need to empathise with the disempowered (1992: 3-47). On the other hand, Posner, an eminent judge and legal scholar, is sceptical about such claims for L\&L, asserting that "the extent to which law and literature have been mutually illuminated is modest" (1988: 13).

4 The movement spawned the journal Law and Literature in 1988 and led to L\&L courses in many US law schools. It has been adopted by some academics in the UK: Ward (1995) concentrates on the educative ambition of L\&L, while Aristodemou (2000) takes a psychoanalytical and feminist approach. More recently L\&L has gained a foothold in the French-speaking world, particularly with Ost (2004) and the launch in 2017 of the journal Droit et litterature. L\&L scholars tend to have a legal rather than a literary background, with the notable exception of Biet (2002).

The nexus between law and literature today can be analysed in terms of three areas: "law as literature", an essentially language-based approach which studies legal texts through the prism of linguistic, literary and rhetorical techniques; secondly, a minor but emerging approach entitled "literature in law", which studies literary references used by legal professionals in their decisions and opinions (Gadbin-George, 2013); and, finally, the more widespread "law in literature" approach adopted in this article, which Dunlop defines as follows:

"Law in literature" is, as the name suggests, the study of representations of the legal order in fiction, usually novels and plays. Courses on the subject require students to read several books in which the law plays a significant role. Elizabeth Gemmette's recent survey of Law and Literature courses offered in American law schools lists over 100 authors and over 150 different novels, plays, short story collections, and poems read in such courses. Some obvious candidates like Camus, Dickens, Kafka, Melville, and Shakespeare appear on several reading lists, but other instructors range further afield to include everything from Aeschylus to Agatha Christie. (1991: 63)

6 This article is located at the beginning of the timeline, focusing on Aeschylus' Oresteia (458 BC), which contains the first courtroom drama in Western literature. To sum up briefly, the trilogy begins with the victorious return of Agamemnon from the Trojan war. He is immediately murdered by his wife Clytemnestra in revenge for the sacrifice of their daughter Iphigenia. Many years later their son Orestes returns from exile. He in turn murders Clytemnestra to avenge the killing of Agamemnon and is immediately pursued by the Furies, ancient crones who punish kin-killers. The case is brought before the goddess Athena; she sets up a court to judge Orestes, who is acquitted.

The aim of this article is to analyse the justice-related issues foregrounded in the Oresteia through the prism of contemporary thinking. It studies the trilogy in the light of tensions between different legal concepts (private justice vs the rule of law, strict liability vs negligence, adversarialism vs conciliation, etc.). These tensions underpin the structure and meaning of the trilogy and raise important ethical questions which are as relevant today as they were in the 5th century BC. The first part centres on the various power struggles in the plays, especially gender battles; the second part shows 
how language is used as an instrument of empowerment; and finally, we argue in favour of the use of such classics within the scope of French academic ELP teaching.

\section{Power struggles in the Oresteia}

Athens in the fifth century BC was the scene of almost constant conflict. On the military front the Persian Wars (499-449 BC), including the battles of Thermopylae, Salamis, Plataea and Mycale, were followed by the Peloponnesian War (431-404 BC) against Sparta and its allies. Meanwhile, on the domestic front Athens witnessed a seismic shift from oligarchy to democracy, starting with the reforms introduced by Cleisthenes in $507 \mathrm{BC} .{ }^{5}$

These multiple conflicts, both external and internal, are reflected by a series of power struggles in the Oresteia. Central to these struggles is the tension between a private and a civic form of justice, which informs the balance of power between the individual and the State, gods and humans, old gods and young gods, and reactionaries and radicals. The move towards a new order also gives rise to gender-related power struggles.

\subsection{The individual vs the State}

Under the archaic system of revenge-based justice featured in the trilogy, the responsibility for pursuing and punishing murderers lay not with the State but with the family of the victim. Retribution, the ancient Greeks believed, was divinely ordained: Orestes is ordered by Apollo to avenge the murder of his father Agamemnon, failing which he will incur divine wrath. However, Orestes is faced with an impossible choice since this means he must kill his mother Clytemnestra and, in turn, be hounded by the avenging Furies.

11 Orestes thus finds himself on the cusp of the "tragic moment" identified by Vernant and Vidal-Naquet (1972: 13-17). The emergence of Athenian democracy in the 5th century $\mathrm{BC}$ led to a clash between traditional religious values and the ideology promoted by the new legal and political institutions which, it is argued, gave birth to tragedy. ${ }^{6}$ Whereas lyrical poetry glorified the heroes of legend, the new genre of tragedy placed them at the tipping-point between two idea systems. Orestes, like his distant descendant Hamlet, is caught between the old world and the new order in a classic "double bind", and progresses from one system to the other in the course of the trilogy: in the Libation Bearers he performs the orders of Apollo, whereas in the Eumenides he submits to the rule of law.

The key term here is dike, which acts as a leitmotiv running through the trilogy (Goldhill, 2004: 28-9). Dikē was the goddess of justice, daughter of Zeus and Themis. Her name is also used generically to encompass a wide spectrum of meaning which ranges from "justice" to "revenge" and "punishment", concepts which are nowadays regarded as discrete, and indeed contradictory, but which corresponded to a single term in Ancient Greek.

In the first two parts of the trilogy, Agamemnon and the Libation Bearers, dike is used by the characters to signify revenge. This sets in motion a cycle of reciprocal violence in which the victim is first the avenger, and then the victim of revenge. Thus Clytemnestra avenges Agamemnon's sacrifice of their daughter Iphigenia, which 
enabled the Achaean fleet to set sail for Troy and avenge the abduction of Helen. Orestes exacts retribution on Clytemnestra and is pursued by the Furies, who avenge kin-killers on behalf of the victims. The pattern of reversal, in which every act of revenge calls for counter-revenge, is seemingly endless.

Figure 1. - The pattern of retribution in the Oresteia.

\section{Agamemnon sacrifices his daughter Iphigenia to the gods}

Clytemnestra, his wife, murders Agamemnon to avenge their daughter

Orestes, their son, kills his mother, Clytemnestra, to avenge his father

\section{The Furies hound Orestes for killing his mother}

In the final play, the Eumenides, the goddess Athena is called upon to stem the cycle of violent retribution. The parties put forward their arguments in what is in effect a pretrial hearing and formally submit to her jurisdiction, agreeing that the dispute should be resolved by an impartial judge in place of the traditional system of sworn oaths:

\begin{tabular}{|r|l|}
\hline Athena: & Injustice, I mean, should never triumph thanks to oaths. \\
\hline Leader: & Then examine him yourself, judge him fairly. \\
\hline Athena: & $\begin{array}{l}\text { You would turn over responsibility to me, } \\
\text { to reach the final verdict? }\end{array}$ \\
\hline Leader: & $\begin{array}{l}\text { Certainly. } \\
\text { We respect you. You show us respect. } \\
\text { (Eum. 445-9) }\end{array}$ \\
\hline
\end{tabular}

The scene fictionalises a watershed moment in legal history: instead of taking the law into their own hands, Orestes and the Furies agree to entrust the dispute to a third party, a decision which has been described as the "founding act of law in its entirety" (Ost, 2004: 83).

Athena sets up the Areopagus, presented as the first human court, which was still in existence when the play was performed (see below, 1.4). In so doing, she transfers responsibility for the judgment and punishment of crimes from the individual to the State and, by creating a permanent institution, she ensures that the new legal regime will apply to all subsequent cases. The trilogy which began in the oikos (household) of Agamemnon ends in the polis (city-state) of Athens, a change of locus which reflects the tensions between these two seats of power in fifth-century Athens (Goldhill, 2004: 6). The final scene celebrates the triumph of the polis over the oikos, in other words of the State over the individual. This can be viewed as disempowerment of the citizen or 
alternatively as a form of liberation, since it is no longer the victim's descendants who must bear the burden of avenging the murder and facing the ensuing counter-revenge.

As part of this move from the individual to the collective, dike evolves from a private blood vendetta to a community-based form of justice. It is now closer to the modern meaning of justice, for instance when Athens is described as "your city straight and just" (Eum. 1003). In parallel, there is also a progression from the uncompromising form of strict liability upheld by the Furies to "legal" liability or negligence based on blameworthiness (Posner, 1988: 35-6). This more nuanced approach, which considers factors such as intentionality and duress, is suggested by Athena herself when she enquires "And nothing forced [Orestes] on, no fear of someone's anger?" (438), anticipating the plea in mitigation that it was Apollo who compelled him to commit matricide.

However, this new legal process alone does not achieve lasting resolution of the conflict. There is a hung jury and Orestes is acquitted on Athena's casting vote. Having been disavowed, the Furies now present themselves not as pursuers but as victims, and threaten to take revenge on the entire city of Athens, a turn of events which means the judicial decision must be backed up by political and diplomatic manoeuvring, as will be seen below (1.3).

\subsection{The gods vs humans}

19 The gods clearly dominate human affairs in the Oresteia. The trilogy opens with the watchman imploring the gods to set him free from pain, and closes with a religious procession. Agamemnon's first words offer praise to the gods for victory in the Trojan war (794-7), while Clytemnestra, Orestes and Electra all invoke divine assistance for their revenge killings. ${ }^{7}$ Orestes repeatedly stresses that he was forced to kill his mother by Apollo, ${ }^{8}$ and when he hesitates his companion Pylades provides a stern reminder of the divine nature of the injunction:

What of the future? What of the Prophet God Apollo,

the Delphic voice, the faith and oaths we swear?

Make all mankind your enemy, not the gods. (Lib. 887-9)

When Athena is called upon to adjudicate the case, she is torn between two conflicting imperatives. Orestes has come to her as a supplicant, having performed the purification ritual, and she has no reason to turn him away, but she cannot deprive her fellowgoddesses the Furies of their right to exact revenge. Just as Orestes hesitated before killing Clytemnestra, so Athena now has a moment of indecision, her gaze straying from one party to another:

So it stands. A crisis either way.

Embrace the one? expel the other? It defeats me. (Eum. 495-6)

21 Her solution is to set up the Areopagus, a court of law presided over by her but with a jury consisting of mortals. This appears to signify disempowerment of the gods in favour of humans, who will deliver the final verdict. However, in this landmark case the proceedings continue, in fact, to be dominated by the gods. After a brief interrogation of the accused, the rest of the hearing consists of rhetorical sparring between the Furies and Apollo; no witnesses are called and no evidence is presented. Indeed, Orestes is the only mortal to speak during the trial. For her part, Athena retains the upper hand over her human counterparts: it is she who hand-picks the jurors from the "finest men 
of Athens" (503), declaring in advance of the verdict that she will have the casting vote in the event of a hung jury.

The gods are evidently unwilling to relinquish their power over mortals, and the fact that the jury is evenly divided suggests that humans are reluctant to take on the burden of the new order. The trial of Orestes should thus be regarded not as an endpoint but as a first step in the emancipation of mortals from the gods. For mortals to be considered fully accountable for their actions, a pre-requisite for asserting the primacy of human justice over divine justice, the gods must first loosen their grip. The conclusion underlines the continuing hold of the gods over humans for, when Orestes leaves the stage, one-third of the Eumenides still remains to be played out and the final, decisive, scene features only goddesses (Athena and the Furies), as we will see in the following section.

\subsection{Old gods vs young gods}

Intergenerational conflict is a recurring theme in the Oresteia. There are sharp exchanges at the end of Agamemnon between the chorus of elders and Clytemnestra (1449-51) and between the chorus and Clytemnestra's lover, Aegisthus, who taunts them about their age (1651-2). In the Libation Bearers the younger generation (Electra and Orestes) plots and performs the murder of the older generation (their mother Clytemnestra). Finally, at the level of the gods themselves, there is a sustained struggle in the Eumenides between the Furies, the "older gods" (890) who prosecute Orestes, and the "young god" (151) Apollo who defends him, a divine version of the clash of generations which reflects the tension between the old world and a new order.

In the opening scene of the Eumenides at the temple of Delphi, the Furies accuse Apollo of depriving them of their divine right to avenge kin-killing, thereby preferring humans to fellow-gods (170-1), and hold him personally responsible for the murder of Clytemnestra (197-8). Apollo retorts that violation of the marriage bond (the murder of Agamemnon by Clytemnestra) is as serious an offence as violation of the blood bond (the murder of Clytemnestra by Orestes), and submits the dispute to the jurisdiction of Athena (215-22).

The Furies are aware that if they lose this test case, they will be stripped of their powers. If humans no longer fear divine wrath, they warn, anarchy will ensue:

Here, now, is the overthrow

of every binding law-once his appeal,

his outrage wins the day,

his matricide! (506-9)

In a "floodgates argument" worthy of a modern-day politician, they talk of "a lethal tide to sweep the world" (517). This is the apocalyptic rhetoric of an authority that senses its power is waning. Athena implicitly replies to their objection later in the play, while the court is awaiting the decision of the jury. Replacing the old dispensation, she argues, will lead not to chaos but to a new order in which fear of the gods is replaced by fear of the law:

Where is the righteous man who knows no fear?

The stronger your fear, your reverence for the just, the stronger your country's wall and city's safety. (713-5) 
Following the verdict of the court, Athena engages in negotiations with the Furies who, having lost the case, are now threatening to cast a plague on Athens. The adversarial nature of the proceedings gives way to conciliation and she eventually wins them over with the offer of a permanent resting-place in Athens, where they will be worshipped by her citizens (816-9). Old and young gods now act in unison, and this is demonstrated visually in the closing procession when the Furies dance and sing around Athena, who has in effect become the chorus leader (927-38). This eminently inclusive ending is prefigured by the opening speech of the Eumenides, in which the priestess at Delphi praises all generations of gods from Titans to Olympians (1-30). Polarised forces, the play seems to suggest, are more powerful when they are combined.

While Athena embodies even-handed power, her half-brother Apollo is a more ambivalent figure. On the one hand, by advising Orestes to refer his case to Athena, he initiates the process leading to the creation of the first law court and is dismissive of the rough justice upheld by the Furies (Eum. 183-4); on the other, he was the prime mover in the murder of Clytemnestra, as he himself admits on several occasions (87, 585-6). He is, thus, a rather late convert to the rule of law. He comes across as an arrogant and opportunistic figure: whether at the temple of Delphi or the court of the Areopagus, he offers only insults and threats in response to the calm reasoning of the Furies, retorting with vituperation, for instance, when they point out a contradiction in his arguments (652). ${ }^{9}$ In contrast, the Furies represent a form of moral rectitude by steadfastly upholding the lex talionis, whatever the consequences for them.

Thus the clash between the young Olympian deities and the old chthonian (underground) goddesses is not presented in binary terms as a struggle between high and low, good and evil. Apollo's reference to the omnipotent justice of Zeus (626) and Athena's veiled threat to deploy her father's thunderbolts if the Furies refuse to negotiate (837-8) serve as reminders that the reign of the Olympians is based on the principle of "might is right". Indeed, Zeus himself shares a common ancestry with the Furies, who were born following an act of violence by his father Kronos, whom Zeus in turn overthrew along with the other Titans.

Although the Furies eventually join forces with the Olympians they will continue to pursue humans for the crimes of their forefathers, as Athena acknowledges:

[...] he who has never felt their weight,

or known the blows of life and how they fall,

the crimes of his fathers hale him towards their bar,

and there for all his boasts-destruction, silent, majestic in anger,

crushes him to dust. (Eum. 941-8; cf. 960-8)

Old and new will co-exist, with the pursuit of hereditary sin being incorporated into the new legal order. Thus elements of revenge remain in supposedly enlightened judicial systems, a fact which remains true to this day. ${ }^{10}$ Had Orestes been convicted (and it would have taken just one juror to swing the vote), he would presumably have been sentenced to the death penalty, which is the most extreme form of State-sponsored revenge. Absorbing private justice into the rule of law means that individual violence is not eradicated, but replaced by State violence (Ost, 2004: 132-5). 


\subsection{Reactionaries vs radicals}

This clash between the old dispensation and a new order can also be viewed as a metaphor for the political struggle raging in fifth-century Athens: only two years before the Oresteia was first performed, there had been a civil war between aristocrats and democrats (Goldhill, 2004: 7-11; Hall, 2010: 224-6). The Areopagus, which had previously been an executive and judicial body restricted to the land-owning elite, was opened up to all Athenian citizens and was stripped of its executive powers, becoming solely a law court for homicide cases. Ephialtes, who as leader of the democrats spearheaded these reforms, was assassinated and the culprits were never brought to justice. Consequently, the significance of a long-running dispute being resolved in the Areopagus would not have been lost on an Athenian audience, and Athena's "curse on civil war" (Eum. 875), later reiterated by the Furies (986-8), would have had considerable resonance.

Given the choice of the Areopagus as the setting for the trial, some critics have been tempted to enroll Aeschylus on the side of the democrats, or conversely the aristocrats (Goldhill, 2004: 83-4). In both cases this is probably an over-simplification: in the Eumenides resolution is achieved not by overturning one system in favour of another but by embracing duality. Evidence of this is provided by striking similarities in the "political programmes" set out by Athena and the Furies. In the speech creating the Areopagus, Athena calls on her citizens to strike a balance between the polarised forces of lawlessness and dictatorship:

Neither anarchy nor tyranny, my people.

Worship the Mean, I urge you. (Eum. 709-10)

This echoes an earlier speech by the Furies:

Neither the life of anarchy

nor the life enslaved by tyrants, no

worship neither. (Eum. 536-9)

The parallels between the words of young and old divinities indicate that the new order will not sweep away the past, but will use it as a foundation.

The lines are blurred further after the trial, when Athena engages in eleventh-hour diplomacy to win over the Furies. In a skilful display of dispute resolution (Hall, 2015) she offers them a role as patrons of the city, which they eventually accept. In what is essentially a power-sharing and land-sharing agreement, ${ }^{11}$ Athena does not attempt to overturn the old dispensation but instead incorporates it in a new order, encouraging the Furies to combine forces with her. By enabling the dreaded Furies to regenerate as the Eumenides (the "Kindly Ones"), she transforms a potential source of destruction into a force for good.

On implications of this "new deal" is that, by accepting rather than spurning the Furies, civilised society confronts the barbarian within it and sublimates it through a process of regeneration and renewal. Put in modern-day political terms, the play promotes compromise rather than polarisation.

\subsection{Men vs women}

Fifth-century Athens was an unapologetically male-dominated society. Women could not be citizens and were not even referred to as "Athenians" but as "women of Attica" 
(Goldhill, 2004: 4). In this context, it is not surprising that male-female dynamics were an underlying societal issue of the epoch and, consequently, were foregrounded by playwrights, ${ }^{12}$ as pointed out by Moss:

Aeschylus, Euripides and Sophocles responded to the bias of their times with a radical thesis concerning feminine potentiality that has not been articulated again till our time. Their plays show women of aristocratic rank displaying strengths commonly supposed to be the prerogative of men, strengths that when denied or blocked become expressed in destructive behaviour. (1988: 515)

Asymmetrical gender relationships permeate the Oresteia. Whereas asymmetry in gender politics, as we will see, is expressed in terms of either polarisation or absence, female power is also represented as a force of reconciliation.

\subsubsection{Polarisation} a husband, with Medea and Phaedra being the best-known examples. The male anxiety this reflects is not only sexual in nature but also relates to their power over the household, since a nagging fear for an Athenian citizen was the introduction of a son he had not fathered (Hall, 2010: 128-35). The chorus in the Libation Bearers echoes this perceived need to restrain female desire in order to maintain domestic and social order:

She couples with every form of ruin known to mortals.

Woman, frenzied, driven wild with lust,

Twists the dark, warm harness

Of wedded love-tortures man and beast! (Lib. 582-5)

Male-female polarisation is most apparent when Clytemnestra confronts her male partners. She dominates the exchanges with Agamemnon, defeating the victorious general in a war of words and persuading him against his better judgment to enter the palace on a red carpet. This apparently trivial matter is, in fact, the focus of a bitter 
struggle for Agamemnon sees such a show of ostentation as suitable for effeminate Trojans, not virile Greeks. "You treat me like a woman" (Aga.912), he complains, acknowledging the complex gender reversal implicit in this act. The colour of the carpet also prefigures the bloodbath (in the literal sense) which awaits him at the hands of Clytemnestra: "Let the red stream flow" (902), she says, in a line menacing in its ambiguity.

The role reversal becomes even more blatant when Clytemnestra is compared to her lover Aegisthus, who works behind the scenes. He appears only at the end of Agamemnon once the murder has been performed, and clearly plays no part in it:

Woman made [Agamemnon] suffer,

woman struck him down (Aga. 1481-2),

says the chorus, later taunting Aegisthus for not having the courage to commit the act (1676-8).

This portrayal of Aegisthus contrasts sharply with earlier versions of the tale in the Odyssey, with which the original audience of the Oresteia would have been familiar. Aegisthus is presented by Homer as the corrupting influence and is identified on several occasions as the murderer, whereas Clytemnestra plays a less prominent role, being either described as an accomplice or not mentioned at all. ${ }^{13}$ In the Oresteia the opposite is true: Clytemnestra takes the initiative while Aegisthus is a pale, passive figure who "schemed [Agamemnon's] death / but cringed to cut him down with [his] own hand" (1666-7).

Clytemnestra creates a template for seductive murderesses in drama throughout the ages, from Lady Macbeth to Villanelle in the TV series Killing Eve. Naturally, female empowerment comes at a price and it is Clytemnestra who is apportioned all the blame, as will be seen in the following section.

\subsubsection{Absence}

47 Three female characters are conspicuous by their absence in the trial scene of the Eumenides. Although Electra plays a key role in encouraging her brother Orestes to avenge their father's murder in the Libation Bearers, she is not summoned either as a coconspirator or as a witness. After committing the extraordinary transgression of plotting the murder of her mother, she is sent back inside the house by Orestes before he goes off to perform the act (Lib.541-2). She reverts to her traditional role as the unmarried daughter of the household waiting for the male heir to restore order, and is heard no more. Similarly, her late sister Iphigenia, though a pivotal figure in the story since it is her sacrifice which led to the murders of both Agamemnon and Clytemnestra, is not mentioned during the trial. To use a chilling modern euphemism, she is considered mere "collateral damage".

The most emblematic (and problematic) character in terms of absence is Clytemnestra. Having dominated the first two plays in the trilogy, she is curiously sidelined during the trial. It is never explained that she murdered Agamemnon to avenge the killing of Iphigenia, which she claimed as her motive just after performing the act (Aga. 1442-4). Unlike Orestes, she is not afforded the luxury of mitigating circumstances (cf. 1.1). Clytemnestra is by far the most colourful character in the Oresteia, transgressing political, social and sexual norms but, like her daughter Iphigenia, she is sacrificed in order to maintain the patriarchy. 
The trial scene enacts the absence not just of women, but of the mother in the generic sense. For a modern sensitivity the arguments used by Apollo to exculpate Orestes are outrageous. Comparing the acts of revenge performed by Clytemnestra and Orestes, Apollo maintains that killing a woman is a less serious offence than murdering a man, particularly a warrior-king who has just returned victorious from the battlefield (Eum. 631-5). He then uses an astonishing conceit to support the assertion by Orestes that the murder of Clytemnestra was not a violation of the blood bond. The mother, Apollo claims, is not the true parent but merely a vessel in which the seed planted by the father grows to fruition:

The woman you call the mother of the child

is not the parent, just a nurse to the seed,

the new-sown seed that grows and swells inside her.

The man is the source of life-the one who mounts. (Eum. 666-9)

As evidence of this assertion he points to the birth of Athena, who was "never bred in the darkness of the womb" (676) but emerged from the skull of Zeus. ${ }^{14}$ Nowadays such reasoning would be considered manifestly absurd by a court of law, but the idea that children were not biologically linked to their mothers was taken seriously by certain Athenian thinkers at the time. ${ }^{15}$ This belief can be compared to a creation myth recounting how the first inhabitants of Athens sprang from the soil (Goldhill, 2004: 5), a "mother Earth" in the literal sense, thus diminishing the primacy of women as lifegivers.

51 Forced to arbitrate between competing acts of vengeance by a wife and by a son, Athena echoes the argument that she was born without a female intermediary and accordingly declares that she will favour the male party:

No mother gave me birth.

I honour the male, in all things but marriage.

Yes, with all my heart I am my Father's child.

I cannot set more store by the woman's death-

she killed her husband, guardian of their house.

Even if the vote is equal, Orestes wins. (Eum. 751-6)

52 This decision, which has been denounced by feminist critics (Goldhill, 2004: 89-91; Aristodemou, 2000: 66-79), is the most problematic aspect of the Oresteia for a modern audience. As Hall (2010: 224-7) puts it, this play provides a political aetiology or charter myth for the origins of the Areopagus, and a sociological aetiology for male domination of women.

53 From a psychoanalytical point of view, murder of a mother in the Libation Bearers is followed by murder of the mother (in the generic sense) in the Eumenides, when both Apollo and Athena deny that women are creators of life. Aristodemou (2000: 61-3) argues that this matricidal urge stems from the fact that true power is invested in women, not men, through their role as life-givers. Aware that women hold the key to the survival of the patriarchy, and fearful of the power this gives them, men seek to control and repress them. Accordingly, the dual fantasies articulated in the Eumenides (woman as an empty vessel and the pregnant man) posit a world in which men are selfsufficient. 


\subsubsection{Female empowerment} Throughout the trilogy the male characters (Agamemnon, Orestes and Apollo) have wreaked violence and destruction. When the verdict is announced Apollo appears to be the victor, but it is Athena who achieves the ultimate triumph by enlisting the support of the Furies. For the first time in the trilogy, conflict is not centred on a battle of the sexes. Whereas the exchanges based on gender polarisation (Agamemnon vs Clytemnestra, Clytemnestra vs Orestes, Apollo vs the Furies) are marked by discord, the all-female finale leads to reconciliation (see 1.3).

emale power, portrayed as a threat to social order in Agamemnon and the Libation Bearers, becomes a means of pacification in the Eumenides. Athena offers the Furies "nothing that strikes a note of brutal conquest. Only peace" (Eum. 913). She is able to transcend gender divisions because she stands apart from this highly polarised society. Athena has traditional "male" attributes, being associated with both warfare and wisdom, and as a parthénos or virgin she has no male partner and therefore does not conform to traditional gender roles (Goldhill, 2004: 39-40).

Thus the Oresteia simultaneously upholds the patriarchal society in which it was written and contains subversive undertones which undermine it. Its portrayal of gender conflicts shows that a predominantly male-dominated world can only lead to chaos, and that a fine sense of balance between male and female power is required to maintain stability. This is, of course, as true in the 21st century as it was in the 5th century BC.

\section{Power over language and signs}

Power is closely linked to mastery of language, and legal language is often viewed by its detractors as a means by which the few exert power over the many. However, the Oresteia shows that language can also be an instrument of empowerment for the disempowered. Language is part of a broader system of signs studied under the heading of semiotics and, throughout the trilogy, power is predicated on the ability to interpret signs (Goldhill, 2004: 48-55). These two related skills (power over signs and power over language) will now be studied in turn.

\subsection{The interpretation of signs}

57 Signs and their interpretation abound in the Oresteia, ranging from birds, carpets, nets, a lock of hair and footprints to the serpent in Clytemnestra's dream, some of which we will examine here.

The "backstory" to the entire tragedy centres on a sign, as recounted in the opening chorus. The Greeks are stranded at Aulis, unable to set sail for Troy on account of crosswinds. They observe two eagles swooping down to attack a pregnant hare. The prophet Calchas renders a twofold interpretation of this sign: the first part predicts the fall of Troy at the hands of the two generals Agamemnon and Menelaus; the second part of his interpretation, laden with terrible consequences, advocates that, in order to appease the goddess Artemis and gain a fair wind, Agamemnon must sacrifice his 
daughter Iphigenia (Aga.115-216). The sign and its interpretation set off a chain reaction of violence and counter-violence.

In a similar vein, the trilogy opens with another sign, that of the beacon spotted by the watchman, and Clytemnestra's first two major speeches expand on this. She begins with a dramatic account of how the beacon was relayed from one city to another, stressing how it was she who controlled the process (Aga.313). She then explains the significance of the beacon, construing it to signify the fall of Troy, thus endowing herself with power over both transmission and interpretation of the sign which, as the chorus recognises, puts her on an equal footing with men:

Spoken like a man, my lady, loyal,

full of self-command. I've heard your sign

and now your vision. (Aga. 355-7)

In the Libation Bearers, Electra and Orestes also become proto-semioticians. Electra notices a lock of hair on Agamemnon's grave and correctly interprets it as a sign signifying the return of her brother. Orestes also becomes a reader of signs on learning of Clytemnestra's dream in which she gives birth to a snake which bites her breast as she feeds it, causing the blood to curdle the milk (Lib. 514-20). He interprets the dream as a presage of Clytemnestra's death at his hands: as he fed on her milk when a newborn, so he will now draw her blood. The creator of the sign, he says, will be defeated by it:

As she bred this sign, this violent prodigy

so she dies by violence. I turn serpent,

I kill her. So the vision says. (Lib. 535-7)

61 The chorus approves of his interpretation: "You are the seer for me, I like your reading." (538) This sign emboldens Orestes, inciting him to hatch a plan to murder Clytemnestra and Aegisthus using the subterfuge of a disguise (541-65). In so doing, Orestes soon discovers that an essential weapon for the kin-killer is language, as we will now see.

\subsection{Manipulation through language}

62 Clytemnestra is a dominant figure (cf. 1.5.1) and much of her power is exerted through language. When the herald arrives confirming the fall of Troy her immediate reaction is to spread misinformation, instructing him to inform Agamemnon that she awaits his return "just as the day he left her, faithful to the last" (Aga.603). Through her deceitful use of language she lulls her husband into a false sense of security. Agamemnon returns victorious from the war but in the "carpet scene" mentioned above he is immediately defeated in a battle of words by Clytemnestra:

\begin{tabular}{|c|l|}
\hline Clytemnestra: & But the great victor-it becomes him to give way. \\
\hline Agamemnon: & Victory in this... war of ours, it means so much to you? \\
\hline Clytemnestra: & $\begin{array}{l}\text { O give way! The power is yours if you surrender, all of your own free will, to } \\
\text { me! } \\
(\text { Aga. } 936-8)\end{array}$ \\
\hline
\end{tabular}


linguage, performing a ritual incantation with the chorus to curse their enemies and invoke the support of the gods and the spirit of Agamemnon. For them, language and violent revenge are two sides of the same coin:

'Word for word, curse for curse

be born now,' Justice thunders,

hungry for retribution,

'stroke for bloody stroke be paid.

The one who acts must suffer.'

Three generations strong the word resounds. (Lib. 316-20) and his companion, Pylades, imitate "the native tones of Delphi" (551). Through deliberate misinformation (they pretend to be messengers bringing news of the death of Orestes), they gain access to the palace and catch the royal couple unawares. The message from Clytemnestra telling Aegisthus to come with his bodyguards is intercepted and deliberately distorted by the chorus, which tells the nurse to instruct him to come unaccompanied (760), thus leaving him vulnerable to attack. By sending 
false information the chorus helps to correct an injustice: "The teller sets the crooked message straight." (Lib. 763)

On learning of the death of Aegisthus, Clytemnestra realises that, just as she defeated Agamemnon by subterfuge and misinformation (he was unable to read the sign of the red carpet), so she in turn will be killed by her son's trickery with language:

$\mathrm{Ah}$, a riddle. I do well at riddles.

By cunning we die, precisely as we killed. (Lib. 874-5)

\subsection{Reconciliation through language}

71 In the first two plays language is primarily a tool of manipulation, serving as a prelude to physical violence. However, in the Eumenides Apollo promises Orestes that the power of language will lead to resolution of his ordeal:

[...] with a magic spell

-with words-we will devise the master-stroke

that sets you free from torment once for all. (Eum. 84-6)

72 Following Clytemnestra's murder, Orestes is deprived of language since Athenian law forbade murderers to speak until their crime had been purged through a ritual sacrifice (461-4). Once he has been purified by Apollo he can again resort to words, and appeals to Athena to put an end to his torment:

[...] Well I know

the countless arts of purging, where to speak,

where silence is the rule. In this ordeal

a compelling master urges me to speak. (Eum. 274-7; cf. 461-4)

In the courtroom scene, as is the case today, physical violence is replaced by verbal jousting between the prosecution and the defence. However, implicit violence remains just below the surface as the Furies threaten to bring a plague upon the city of Athens if they lose the case (726-7), while Apollo alludes menacingly to the power of his father Zeus (728-9). Language remains an instrument of discord and latent violence, and the uneasy conclusion to the trial, with the jury evenly split, does not bring true resolution.

After the verdict, there is a risk of renewed conflict, and Athena needs to deploy the "soft power" of language to obtain the consent of disgruntled stakeholders. The scene between Athena and the Furies marks the first time in the trilogy that rhetoric is used to promote peace, not violence:

[...] if you have any reverence for Persuasion, the majesty of Persuasion,

the spell of my voice that would appease your fury-

Oh please stay. (Eum. 893-6)

Verbal skill is personified as the goddess Peitho or Persuasion, whom Athena later praises for helping her conduct the negotiations (981-2). As is often the case in the Oresteia, the same forces can be harnessed for good or evil. Athena is pitting the positive power of language against the destructive force of the curses which the Furies are threatening to bring down on Athens:

Let me persuade you.

The lethal spell of your voice, never cast it

down on the land and blight its harvest home. (Eum. 839-41)

76 The old goddesses, who earlier defined themselves as "Curses" (429), eventually acknowledge the superior force of Athena's words and submit to their spell: 
Your magic is working... I can feel the hate, the fury slip away. (Eum. 909) imprecations, on the city of Athens. This transformation is both achieved through language and expressed in language:

Spirit of Athens, hear my words, my prayer

like a prophet's warm and kind. (Eum. 933-4) interpreter, providing a running commentary on the words of the Furies $(939,960,979$, 997). Language is no longer an instrument of manipulation and deception; it has become a means of reconciliation. The power of the word, it would appear, triumphs over the power of the sword.

Or perhaps it does not. It is an open question whether a fragmented society can be held together by an entity as indeterminate as language. Pointing to the multiple interpretations of the key term dike (cf. 1.1) and the numerous instances in the trilogy where words are used to distort reality, Aristodemou concludes that language is an "unsure foundation" for such a project. If we lose faith in language, the whole legal edifice begins to crack:

From questioning the role of language it is only a short step to questioning the social order constituted by this language: the legal order, we are led to suspect, is built on a singularly unsure foundation. (2000: 66)

One of the paradoxical but enduring strengths of the Oresteia is its fundamental ambiguity, which allows for multiple readings. Like dike, the tragedy has different, and at times diametrically opposed, meanings for different people; like the protagonists, we interpret the signs in the work through the prism of our own contemporary history, ideology and personal sensitivity.

\section{Conclusion}

81 If the Oresteia is widely cited in the framework of Law and Literature studies, the relevance to ELP studies of a law-related Greek tragedy written nearly 2,500 years ago needs some explanation.

Most ESP teachers and scholars agree that the initial goal of mainstream ESP studies, as defined with the emergence of the discipline in the 1960s, is to enable learners to acquire the lexical and syntactic fundamentals of the language so as to meet immediate needs with regard to specific tasks in a limited context. Variously defined as "narrowangled" or "narrow context" ESP, and in spite of major evolutions in the field of needs analysis, such goals remain valid in a great number of contexts today, English for pilots and traffic controllers being one emblematic example.

As mentioned in the foreword to this issue, a great deal of ESP teaching in France and other European countries takes place in an academic setting, and consequently targets both immediate and future needs. This calls for a broad-angled approach in keeping with undergraduate and graduate learners whose objective is to join the international professional community not as fringe members but as active stakeholders. This broadangled approach was summed up in 2004 by Petit, who defined the French approach in terms of a language-discourse-culture triptych, a perspective echoed by Parkinson and her "expanding focus of ESP" (2013: 156) with regard to scientific domains. 

being closely linked to learner profiles. ELP teaching, in the French context, concerns not only law school undergraduates and graduates but also judges, lawyers and other legal professionals. One important characteristic of their profile is that the great majority of these learners took a philosophy course for the baccalauréat, the French general high-school leaving certificate, which introduced them to Ancient and contemporary philosophers, if not necessarily to the dramatists themselves. In addition, one of the important courses in first-year law studies is the history of ideas, pertaining to the evolution of thinking in connection with (public) law and including such philosophers as Machiavelli, Spinoza, Hobbes, Rousseau, Kant, etc. In light of this, once graduate students are familiar with the basic language and notions of law, it is quite possible to envisage an introductory course designed as a shift from the language, discourse and culture of law to concepts in law such as those found in the Oresteia. These concepts include the grey areas between right and wrong, conflicts between new and old, reconciliation, gender issues, and the paradigmatic shift from individual revenge to community justice, as Euben sums up: "The trilogy is about the emergence of justice as a distinctive attribute of political life and drama's role in sustaining both." (1982: 24) In so doing, ELP converges towards one of the main principles underpinning the Law and Literature movement, namely how literature can shed light on and provide insights into certain general legal concepts.

Far from being a mere source of abstract input or classroom activity, classical drama can be used in a holistic communicative context by actually being performed, as was the case in 2006 when the Grenoble Law School Students' Association scheduled a lawrelated slam session (in French) and a scene from The Merchant of Venice (in English) after its annual Moot Court. In 2009, in Germany, Reutlingen University's Business English Theatre Project produced Macbiz-an adaptation of Macbeth-in the context of an English for Business Purposes class (and was awarded the European Language Label 2010 for its innovative approach to vocational learning). In France, Giebert reports on the staging of The Merchant of Venice by students specialising in business and finance to focus on contract law, and concludes on the holistic nature of language acquisition it entails:

Drama [serves] as a means to acquire linguistic and non-linguistic competences for their future professional field. It can be used to teach grammar, pronunciation, vocabulary, intercultural aspects, and so-called soft skills such as presentation competence, teamwork skills and self-management. (2014: 150)

A moot court based on the Oresteia could be organised along similar lines, applying contemporary legal concepts and issues such as lawful killing and negligence. The judge would need to decide whether Apollo's "evidence" on the role of the mother, and more generally his attempts to shift the focus from Orestes to Clytemnestra, are admissible, and would also need to prevent both parties putting pressure on the jurors. Staging the trial of Orestes would also involve a comparison of trial procedure in France and common law countries, since a choice would have to be made between the 
clear division of roles between judge and jury in common law courts, and the mixed system used in the French cour d'assises where the judges retire with the jury, as is the case in the Areopagus.

The Oresteia may, at first, seem remote to a 21st century audience, but the numerous revivals and retellings of the trilogy in recent years ${ }^{16}$ testify to its relevance today. It is surely no coincidence that there has been renewed interest in the work at a time when political and legal institutions, and indeed the very principle of representative democracy, are coming under challenge. As such, modern-day law students can easily relate to the age-old issues raised in a world riven apart by seismic changes.

\section{BIBLIOGRAPHY}

AEschYLUS, The Oresteia: Agamemnon, The Libation Bearers, The Eumenides, translated by Robert

Fagles (1977), London: Penguin.

ARISTODEMOU Mària (2000), Law \& Literature: Journeys from Her to Eternity, Oxford: Oxford University Press.

BIET Christian (2002), Droit et littérature sous l'Ancien Régime. Le Jeu de la valeur et de la loi, Paris: Champion.

CARDOZo Benjamin (1925), "Law and Literature”, Yale Law Review, 14, 699-718.

DunLoP C.R.B. (1991), "Literature Studies in Law Schools", Cardozo Studies in Law and Literature, 3(1), 63-110, <www.jstor.org/stable/743502>.

Euben Peter J. (1982), “Justice and the Oresteia”, American Political Science Review, 76(1), 22-33.

GADBIN-GEORGE Géraldine (2013), “To Quote or Not to Quote: ‘Literature in Law’ in European Court Decisions and Legal English Teaching”, ASp, 64, 75-93.

GIEBERT Stefanie (2014), "Drama and Theatre in Teaching Foreign Languages for Professional Purposes”, Recherche et pratiques pédagogiques en langues de spécialité, 33(1), 138-50.

GolDHILL Simon (2004), Aeschylus: The Oresteia, Cambridge: Cambridge University Press.

HALL Edith (2010), Greek Tragedy: Suffering under the Sun, Oxford: Oxford University Press.

HALL Edith (2015), "Peaceful Conflict Resolution and Its Discontents in Aeschylus's Eumenides", Common Knowledge, 21, 253-69.

ISANI Shaeda (2011), "Developing Professional Cultural Competence through the Multi-Layered Cultural Substrata of FASP: English for Legal Purposes and M. R. Hall's The Coroner", Cahiers de l'APLIUT, 30(2), 29-45, <https://doi.org/10.4000/apliut.1497>.

Moss Leonard (1988), "The Critique of the Female Stereotype in Greek Tragedy”, Soundings: An Interdisciplinary Journal, 71(4), 515-32.

OST François (2004), Raconter la loi. Aux sources de l'imaginaire juridique, Paris: Odile Jacob. 
PARKINSON Jean (2013), "English for Science and Technology”, B. Paltridge \& S. Starfield (eds), The Handbook of English for Specific Purposes, West Sussex: Wiley-Blackwell, 155-68.

PETIT Michel (1999), "La fiction à substrat professionnel : une autre voie d'accès à l'anglais de spécialité”, ASp, 23-26, 57-81.

PETIT Michel (2004) “Quelques réflexions sur la fiction à substrat professionnel : du général au particulier”, M. Petit \& S. Isani (ed.), Aspects de la fiction à substrat professionnel, Bordeaux: Université Victor Segalen - Bordeaux 2, 3-23.

POSNER Richard A. (1988), Law and Literature: A Misunderstood Relation, Cambridge, Mass.: Harvard University Press.

VERNANT Jean-Pierre \& VIDAL-NAQUeT Pierre (1972), Mythe et tragédie en Grèce ancienne (t. 1), Paris: La Découverte.

WARD Ian (1995), Law and Literature: Possibilities and Perspectives, Cambridge: Cambridge University Press.

WEISBERG Richard (1992), Poethics: And Other Strategies of Law and Literature, New York: Columbia University Press.

WEISBERG Robert (1989), “The Law-Literature Enterprise”, Yale Journal of Law \& the Humanities, 1(1), <https://digitalcommons.law.yale.edu/yjlh/vol1/iss1/4>.

WHITE James Boyd (1973), The Legal Imagination (abridged edition 1985), Chicago: University of Chicago Press.

WigmoRE John H. (1908), “A List of Legal Novels”, Illinois Law Review, 2, 574-93.

\section{NOTES}

1. ELP: English for Legal Purposes.

2. LSP: Languages for Specific Purposes.

3. See the inceptive article by Petit (1999), a French linguist and ESP specialist.

4. For a critical overview of L\&L scholarship, see Weisberg (1989) and Ward (1995: 3-27).

5. Aeschylus was in his late teens when the democratic process began and fought in the Persian Wars.

6. Weisberg (1992: 202) mentions other periods when law was the dominant cultural and political force and figured prominently in literary discourse, including Elizabethan and Jacobean England, and Europe and America since the Industrial Revolution.

7. Aga. 975; Lib. 248-51.

8. Lib. 273-81, 545-6; Eum. 479-81.

9. Apollo invokes Zeus to assert the superior interest of the father but, the Furies remind him, Zeus himself rose up against his father Kronos (Eum. 647-50).

10. As Posner (1988: 25) points out, law grew out of revenge and many modern legal doctrines continue to reveal traces of their origins in retribution.

11. "Look, / it is all yours, a royal share of our land" (Eum. 897-8).

12. Aristophanes' comedy Lysistrata ( $411 \mathrm{BC}$ ) highlights gender issues in Ancient Greece.

13. At the beginning of the Odyssey Zeus regrets that Aegisthus did not heed his advice not to kill Agamemnon and marry Clytemnestra (Book 1). In Book 4, Menelaus (Agamemnon's brother) puts the blame chiefly on Aegisthus, and the "old man of the sea" Proteus recounts the tale without even mentioning Clytemnestra. In Book 11 the ghost of Agamemnon rails against Clytemnestra 
but describes her as the accomplice, not the murderer. Only in Book 24 does Agamemnon say that Clytemnestra actually killed him.

14. According to mythology, Zeus was told that his wife Metis, who was pregnant, would give birth to a son who would take the throne from him, just as he had seized power from his father Kronos. Accordingly, he turned Metis into a drop of water and swallowed her. When he subsequently complained of a severe headache, Hephaistos split open his skull and Athena emerged from Zeus' brow, fully grown and in armour.

15. Hall (2015: 261-2) explains that this theory was put forward by some esoteric philosophical schools. However, she doubts the audience would have been persuaded by Apollo's argument since Athenian law only permitted men to marry their half-sisters if they had different mothers (not fathers), which suggests the biological link with the mother was considered stronger than the bond with the father.

16. There were three major productions in the UK in 2015 (at Home in Manchester, and at the Almeida and Globe theatres in London) and the same number in France in 2019 (at the ComédieFrançaise in Paris, the Nuits de Fourvière festival in Lyon and the Avignon festival). The Greek director Yorgos Lanthimos revisited the myth in the film The Killing of a Sacred Deer (2017).

\section{ABSTRACTS}

After a brief overview of the Law and Literature movement, this article suggests possible convergences with ESP teaching and the use of classical Greek tragedy. It takes as a "case study" the Oresteia ( $458 \mathrm{BC})$, a trilogy by Aeschylus which features the first courtroom drama in Western literature. The first part of the article illustrates how tensions between a private and a civic form of justice lead to a series of power struggles, particularly between men and women. The following part shows how true power is predicated on mastery of language and signs. The conclusion suggests ways in which classical drama can be used by ESP instructors, given that the issues raised are as relevant today as they were in the 5th century BC.

Après un bref aperçu du mouvement "Droit et littérature ", cet article propose des points de convergence avec l'enseignement de l'anglais de spécialité et l'utilisation de la tragédie grecque classique. Il prend comme «cas d'espèce » l'Orestie (458 avant J.-C.), une trilogie d'Eschyle où figure le premier drame de prétoire de la littérature occidentale. La première partie de l'article montre comment les tensions entre justice privée et justice d'État donnent lieu à des luttes de pouvoir, notamment entre les hommes et les femmes. Dans la deuxième partie, on voit que le véritable pouvoir appartient à celui ou celle qui maîtrise la langue et les signes. La conclusion propose des pistes permettant aux enseignants d'anglais de spécialité d'exploiter le théâtre classique, étant donné que les problématiques soulevées sont aussi pertinentes aujourd'hui qu'au Vème siècle avant notre ère.

\section{INDEX}

Keywords: law and literature, FASP, ESP, tragedy, power, language

Mots-clés: droit et littérature, FASP, anglais de spécialité, tragédie, pouvoir, langue 


\section{AUTHOR}

\section{MALCOLM HARVEY}

Université Lumière Lyon 2.

Malcolm Harvey is a Senior Lecturer at Université Lumière Lyon 2, France. His main research interests are translation, legal language, and more recently law and literature.

He has published a number of articles on legal translation, and has authored several translation handbooks (most recently Exercices de thème anglais, Éditions universitaires européennes, 2016). He is co-author of a textbook on the English and US legal systems (Droit anglais et droit américain, Armand Colin, 2011).

malcolm.harvey@univ-lyon2.fr 